\title{
Postępy w diagnostyce i leczeniu chorych na szpiczaka plazmocytowego
}

\author{
Advances in diagnosis and treatment of patients \\ with plasma cell myeloma
}

\author{
Krzysztof Jamroziak
}

Klinika Hematologii, Instytut Hematologii i Transfuzjologii, Warszawa

\begin{abstract}
Streszczenie
Od prawie dwóch dekad dokonuje sie niezwykly postęp w terapii szpiczaka plazmocytowego wyrazajacy sie nieustanna poprawa rokowania. W ostatnich 5 lat nastapita dalsza optymalizacja schematów chemioterapii zawierajacych leki immunomodulujace $i$ inhibitory proteasomu na podstawie wyników licznych duzych, randomizowanych badań klinicznych 3. fazy. Ponadto trwaty intensywne poszukiwania nowych molekularnych celów terapii, które pozwolityby na jej indywidualizacje oraz przełamywanie oporności na wcześniej stosowane leki. Spośród obecnie badanych nowych strategii terapeutycznych największe nadzieje budzi immunoterapia, $w$ tym szczególnie przeciwciała monoklonalne skierowane przeciwko antygenowi CD38.
\end{abstract}

Słowa kluczowe: szpiczak plazmocytowy, diagnostyka, leczenie, leki immunomodulujące, inhibitory proteasomu, przeciwciała monoklonalne

Hematologia 2015; 6, 1: 10-18

\begin{abstract}
During nearly two decades there has been continuous progress in the therapy of plasma cell myeloma resulting in significant prolongation of patients' overall survival. Since 2010 the efficacy and toxicity of chemotherapy regimens including immunomodulatory drugs and proteasome inhibitors have been further optimized based on the results of numerous, large phase 3 randomized clinical trials. Moreover, intensive efforts have been made to identify novel molecular drug targets to individualize treatment and overcome resistance to existing therapies. Currently, the most promising therapeutic strategy is immunotherapy, especially development of monoclonal antibodies against CD38 antigen.
\end{abstract}

Key words: plasma cell myeloma, diagnosis, therapy, immunomodulatory drugs, proteasome inhibitors, monoclonal antibodies

Hematologia 2015; 6, 1: 10-18

\section{Wprowadzenie}

Odkrycie w 1999 roku skuteczności talidomidu, pierwszego przedstawiciela tak zwanych leków immunomodulujących (IMiD, immunomodulatory drugs), u pacjentów z nawrotem szpiczaka plazmocytowego (PCM, plasma cell myeloma) opornym na konwencjonalne leki cytotoksyczne zapoczątkowa-

Adres do korespondencji: Krzysztof Jamroziak, Klinika Hematologii, Instytut Hematologii i Transfuzjologii, ul. Indiry Gandhi 14, 02-775 Warszawa, tel. 223496 291, faks 223496 213, e-mail: krzysztof.jamroziak@wp.pl 
ło dynamiczny postęp w leczeniu tego nowotworu [1]. Zastosowanie w terapii trzech nowych leków, talidomidu — jego bardziej aktywnego analogu lenalidomidu oraz bortezomibu — pierwszego leku $\mathrm{w}$ klasie inhibitorów proteasomu (IP) spowodowało znaczną poprawę rokowania [2].

Należy zauważyć, że w początkowych latach pierwszej dekady XXI rozwój terapii PCM był dość chaotyczny, co było szczególnie widoczne $\mathrm{w}$ konstrukcji wielu projektowanych $\mathrm{w}$ tym czasie badań klinicznych. W kolejnym okresie ustaliły się jednak bardziej precyzyjne kierunki rozwoju, w tym identyfikacja najbardziej aktywnych schematów terapii skojarzonej zawierających leki z grup IMiD i IP oraz ich konsekwentne porównywanie w randomizowanych próbach klinicznych 3. fazy. Ważne badania kliniczne prowadzono zarówno wśród chorych młodszych będących kandydatami do chemioterapii wysokodawkowanej wspomaganej przeszczepieniem autologicznych krwiotwórczych komórek macierzystych (auto-HSCT, autologous hematopoietic stem cells transplantation), jak i pacjentów niekwalifikujących się do tej procedury. Wyniki tych badań przyczyniły się istotnie do dalszej poprawy wyników leczenia w kolejnych latach [3]. Jedną $z$ obserwacji potwierdzających dalsze przedłużenie mediany czasu przeżycia całkowitego (OS, overall survival) chorych w tym okresie są wyniki retrospektywnej analizy ponad 1000 chorych leczonych w znanym ośrodku amerykańskim Mayo Clinic w latach 2001-2010. Wykazano, że OS chorych leczonych w tych latach było istotnie dłuższe niż w pierwszej połowie dekady, osiągając medianę 7,3 roku. Co istotne, poprawa rokowania $\mathrm{w}$ tym okresie dotyczyła głównie pacjentów starszych, którzy we wcześniejszych analizach odnosili mniejszą korzyść z nowoczesnych terapii [3].

Dynamiczny rozwój leczenia chorych na PCM był kontynuowany w latach 2010-2015. Jego istotnym wykładnikiem była między innymi rejestracja w Stanach Zjednoczonych dwóch nowych leków do terapii PCM, karfilzomibu $z$ grupy IP i pomalidomidu $z$ klasy IMiD (w Europie dotychczas zarejestrowano tylko pomalidomid). Od 2010 roku na łamach czasopisma „Hematologia” corocznie są prezentowane przeglądy najważniejszych doniesień z Konferencji Amerykańskiego Towarzystwa Hematologicznego (ASH, American Society of Hematology). Jednak dopiero $z$ perspektywy czasu okazuje się, które $z$ tych ściśle wyselekcjonowanych obserwacji są na tyle istotne, aby otworzyć nowe kierunki badań lub zmienić obowiązujące standardy postepowania. Niniejsza praca jest próbą podsumowania odkryć dotyczących biologii i terapii dokonanych w ostatnich 5 latach, które przyczyniły się, lub $z$ dużym prawdopodobieństwem się przyczynią w najbliższej przyszłości, do zmiany praktyki klinicznej.

\section{Badania przedkliniczne}

Postęp technologiczny w zakresie metod biologii molekularnej umożliwia coraz dokładniejsze poznanie mechanizmów onkogenezy, jak również przyczyn wrażliwości i oporności na poszczególne klasy leków przeciwnowotworowych. W odniesieniu do badań przedklinicznych w obszarze PCM na wyróżnienie zasługują szczególnie dwa odkrycia dokonane w ostatnich kilku latach. Pierwsze $z$ nich to seria doniesień ukazujących mechanizmy działania IMiD. W 2010 roku grupa badaczy z Tokijskiego Instytutu Technologii opublikowała niezwykle ważną pracę, w której udowodniono, że cereblon (CRBN), mało dotychczas znane białko tworzące wraz $z$ innymi składowymi (DDB1, Cul4A i Rbx1) kompleks E3 ligazy ubikwitynowej, jest molekularnym celem dla talidomidu i pośredniczy w teratogenności tego leku [4]. W kolejnych latach wykazano, że wszystkie IMiD (talidomid, lenalidomid i pomalidomid) wiążą CRBN, co zwiększa powinowactwo kompleksu E3 ligazy ubikwityny do dwóch czynników transkrypcyjnych biorących udział w różnicowaniu limfocytów B - IKZF1 (Ikaros) i IKZF3 (Aiolos) $[5,6]$. W następstwie ubikwitynacji dochodzi do wybiórczej degradacji IKZF1 i IKZF3, co odpowiada za cytotoksyczny efekt IMiD w stosunku do nowotworowych plazmocytów. Na liniach komórkowych PCM wykazano, że wyłączenie w komórce genu $C R B N$ uniemożliwia działanie IMiD oraz że jego niska ekspresja jest powszechnym mechanizmem oporności na leki $z$ tej grupy [5, 6]. Ponieważ IKZF3 jest represorem ekspresji interleukiny 2 (IL-2), wyjaśniono również zagadkę immunomodulacyjnego działania IMiD polegającego na stymulacji uwalniania IL-2 przez limfocyty T $[5,6]$. Choć badania te nie wyjaśniają wszystkich niejasności związanych $z$ wielokierunkowymi efektami działania IMiD, to są bardzo ważnym krokiem na drodze do opracowania bardziej celowanej i indywidualizowanej terapii PCM i innych nowotworów.

Drugim niezwykle interesującym kierunkiem badań były prace nad mechanizmami ewolucji klonalnej PCM na poziomie subklonalnym oraz mechanizmów ewolucji klonalnej. Na podstawie wyników złożonych analiz molekularnych, głównie z zastosowaniem technik głębokiego sekwencjonowania, udowodniono istnienie złożonej hierarchii subklonalnej już na bardzo wczesnym etapie 
onkogenezy PCM $[7,8]$. Ponadto dzięki analizom materiału $z$ kolejnych nawrotów stwierdzono, że klony konkurują ze sobą i podlegają mechanizmom selekcji, podobnie jak w modelu ewolucji zaproponowanym przez Darwina [7, 8]. Istotnym, ale nie jedynym, czynnikiem selekcji jest ekspozycja na leki przeciwnowotworowe (tzw. pływy klonalne). Ta nowo odkryta znaczna heterogenność subklonalna PCM jest silnym argumentem przemawiającym za stosowaniem złożonej i długotrwałej chemioterapii, która atakowałaby największą liczbę subklonów i pozwoliła uniknąć selekcji klonów bardziej opornych i agresywnych [9].

\section{Metody diagnostyczne i ocena zaawansowania}

Do najbardziej istotnych obszarów rozwoju należy zaliczyć rosnąca rolę $\mathrm{w}$ diagnostyce PCM nowych technik obrazowych, przede wszystkim jądrowego rezonansu magnetycznego (NMR, nuclear magnetic resonanse) i pozytonowej tomografii emisyjnej (PET, positron emission tomography)/ /tomografii komputerowej (CT, computed tomograpy). Badania te mają istotne znaczenie szczególnie w przypadku braku zmian osteolitycznych w standardowej ocenie za pomocą klasycznych zdjęć rentgenowskich. Ponadto techniki te przyczyniły się ostatnio do ustalenia epidemiologii i znaczenia rokowniczego pozaszpikowych guzów typu plasmocytoma (EMP, extramedullary plasmocytoma). W analizie retrospektywnej hiszpańskiego badania PETHEMA/GEM05, w którym porównywano trzy nowoczesne schematy indukujące przed auto-HSCT (VTD [bortezomib, talidomid, deksametazon] $v$. TD [talidomid, deksametazon] v. VBMCP [winkrystyna/karmustyna/melfalan/cyklofosfamid/prednizon]/VBAD/bortezomib) stwierdzono występowanie EMP u 66 (17\%) pacjentów [10]. Co istotne, chorzy na EMP stanowili źle rokująca grupę mimo podobnego odsetka negatywnych zmian cytogenetycznych jak u pozostałych pacjentów. Podobne obserwacje pochodzą również $Z$ innych uznanych ośrodków [11]. Z tego powodu stwierdzenie EMP obecnie powszechnie zalicza się do kryteriów bardzo wysokiego ryzyka (ultra-high risk).

Wykazano również przydatność badań NMR i PET/CT w ocenie choroby resztkowej i ocenie ryzyka nawrotu, szczególnie u pacjentów leczonych za pomocą auto-HSCT. W grupie 192 chorych stwierdzono, że dodatni wynik badania PET/CT w 3. miesiącu po zabiegu auto-HSCT jest niezależnym czynnikiem ryzyka krótszego czasu do progresji choroby (PFS, progression-free survival) i krótszego OS [12]. W innej retrospektywnej analizie 100 chorych wykazano, że liczba zmian ogniskowych w szpiku widocznych w badaniu NMR przed i po zabiegu auto-HSCT wykazuje istotny statystycznie wpływ na PFS, a także OS [13]. Wydaje się więc, że nowoczesne techniki obrazowe mogą być przydatne do identyfikacji chorych wymagających dodatkowej intensyfikacji leczenia, na przykład konsolidacji lub terapii podtrzymującej, jednak jest to jeszcze przedmiotem badań.

Kolejną bardzo istotną obserwacją w odniesieniu do oceny zaawansowania i rokowania były wyniki wieloośrodkowego randomizowanego badania QUIREDEX grupy hiszpańskiej służącego porównaniu schematu LDex (lenalidomid w skojarzeniu $z$ małymi dawkami deksametazonu) z placebo u chorych na PCM tlącego się o wysokim ryzyku progresji [14]. Wstępne wyniki w grupie ocenionych 50 pacjentów wskazują, że podawanie lenalidomidu $z$ deksametazonem i następnie podtrzymywanie lenalidomidem jest dość dobrze tolerowane i umożliwia nie tylko opóźnienie progresji, ale również wydłużenie OS; po 3 latach od włączenia do badania $93 \%$ versus $76 \%, p=0,04$ [14]. Na podstawie ostatniej, długoletniej obserwacji (mediana $>5$ lat) obu grup badania prawdopodobieństwo przeżycia 7 lat ocenia się obecnie na $94 \%$ w grupie chorych leczonych według schematu LDex oraz tylko $64 \%$ w grupie otrzymującej placebo. Wyniki te stanowiły przekonujące uzasadnienie dla wczesnego rozpoczęcia leczenia u chorych na PCM tlącym się wysokiego ryzyka [14].

Udowodnienie celowości leczenia bezobjawowego PCM wysokiego ryzyka, a także coraz powszechniejsze stosowanie NMR i PET/CT należały do istotnych powodów aktualizacji kryteriów diagnostycznych PCM przez Międzynarodową Grupę Roboczą ds. Szpiczaka (IMWG, International Myeloma Working Group) [15]. W nowych kryteriach zdefiniowano kategorię chorych bez objawów klinicznych, którzy kwalifikują się do rozpoczęcia chemioterapii ze względu na obecność określonych czynników wskazujących na duże prawdopodobieństwo szybkiej progresji do objawowego PCM [15].

\section{Leczenie pierwszej linii}

\section{Pacjenci kwalifikujący się do auto-HSCT}

W odniesieniu do kandydatów do auto-HSCT najistotniejsze pytania, na które próbowano odpowiedzieć w ostatnich latach, dotyczyły wyboru najlepszego schematu indukującego remisję, optymalnego czasu wykonania auto-HSCT, a także 
potencjalnego miejsca w terapii I linii dla tandemowego auto-HSCT i przeszczepienia allogenicznych krwiotwórczych komórek macierzystych (allo-HSCT, allogeneic hematopoietic stem cells transplantation).

Na podstawie wielu badań klinicznych ustalono, że leczenie indukujące remisję u kandydatów do auto-HSCT powinno być przeprowadzone według schematów trójlekowych, do których należą VTD, VCD (bortezomib, cyklofosfamid, deksametazon), PAD (bortezomib, doksorubicyna, deksametazon) oraz VRD (bortezomib, lenalidomid, deksametazon). Schematy $z$ bortezomibem nie przełamują całkowicie niekorzystnego wpływu negatywnych cytogenetycznych czynników rokowniczych, w tym szczególnie związanych $z$ obecnością $t(4,14)$ i del17p, poprawiaja jednak rokowanie w tych grupach pacjentów. Jednocześnie nie wykazano, aby układy czterolekowe miały nad nimi przewage pod względem efektywności, natomiast wydają się bardziej toksyczne. Do ugruntowania pozycji trójlekowych schematów opartych na bortezomibie przyczynił się między innymi końcowy raport dużego badania 3. fazy grup HOVON i GMMG, w którym porównano grupę objętą leczeniem indukującym remisję według schematu PAD i podtrzymywaniem po auto-HSCT bortezomibem $z$ grupą, w której w leczeniu indukującym stosowano VAD, a w leczeniu podtrzymującym - talidomid [16]. W populacji analizowanych 713 chorych stwierdzono istotną przewage grupy leczonej $z$ zastosowaniem bortezomibu pod względem odsetka odpowiedzi po auto-HSCT, PFS i OS [16].

Zgodnie $z$ wynikami dostępnych retrospektywnych porównań optymalnym schematem indukującym wydaje się obecnie VTD, natomiast schematy PAD i VCD charakteryzują się nieco mniejszą i porównywalną aktywnością. Ostatnio na podstawie retrospektywnego porównania schematów indukujących VTD oraz VCD wykazano przewagę VTD [17]. W tej analizie porównano grupy chorych pochodzące $z$ dwóch różnych europejskich badań randomizowanych (schemat VTD — badanie GIMEMA MMY-3006; schemat VCD - badanie EMN-02), odpowiednio dobrane pod kątem wieku, płci i czynników rokowniczych [17]. Wykazano, że schemat VTD powoduje istotnie wyższy odsetek odpowiedzi klinicznych (93\% v. 84\%; p < 0,001), a także znamiennie wyższy odsetek odpowiedzi całkowitych $(19 \%$ v. $7 \%$; $\mathrm{p}<0,0001)$. Powikłania hematologiczne 3. i 4. stopnia były częstsze u chorych leczonych za pomocą VCD, jednak schemat VTD wiązał się ze zwiększonym ryzykiem polineuropatii 3. lub 4. stopnia (7\% v. 2\%). Można więc wniosko- wać, że schemat VTD jest obecnie najbardziej uzasadnionym wyborem $\mathrm{w}$ indukcji przed auto-HSCT, jednak wiąże się z ryzykiem neurotoksyczności.

$\mathrm{W}$ odniesieniu do potencjalnych zmian w leczeniu chorych na PCM spodziewanych w bliskiej przyszłości należy wyróżnić doniesienia na temat wysokiej aktywności i dobrej tolerancji trójlekowych schematów indukujących opartych na IP II generacji. Najbardziej zaawansowane są próby kliniczne $z$ karfilzomibem wskazujące na możliwość uzyskania odpowiedzi u prawie $100 \%$ chorych, w tym u 75-80\% pacjentów - co najmniej bardzo dobrych odpowiedzi częściowych (VGPR, very good partial response). Równie interesujące są badania 2. fazy nad skojarzeniem nowego doustnego IP — iksazomibu (MLN9708) — z lenalidomidem i deksametazonem [18]. Ten całkowicie doustny schemat indukujący pozwala na osiągnięcie odsetka odpowiedzi na poziomie $92 \%$, w tym $55 \%$ głębokich odpowiedzi, oraz charakteryzuje się niską toksycznością [18]. Należy jednak poczekać na wyniki odpowiednich badań 3. fazy.

Kolejna istotna kwestia w zakresie leczenia I linii pacjentów młodszych, gorąco dyskutowana w ostatnich latach, dotyczy możliwości odroczenia auto-HSCT do czasu nawrotu PCM. Tendencja do późnego auto-HSCT w dobie bardzo skutecznych nowych schematów indukujących remisję jest faworyzowana głównie przez hematologów amerykańskich, natomiast eksperci europejscy zwykle opowiadają się za przeszczepieniem w terapii I linii. Jako argument przemawiający za odroczeniem auto-HSCT są przytaczane między innymi wyniki retrospektywnych analiz sugerujących, że wykonanie auto-HSCT w nawrocie PCM skutkuje podobnym OS, jak leczenie auto-HSCT w I linii [19]. Jednak wczesne wyniki prowadzonych obecnie dużych badań randomizowanych 3. fazy, których celem było między innymi porównanie obu strategii terapeutycznych, nie pozostawiają wątpliwości, że auto-HSCT w I linii powinno być postępowaniem $Z$ wyboru u wszystkich chorych kwalifikujących się do tej procedury [20].

Kolejnym ważnym tematem jest rola podwójnej transplantacji (tandemowego auto-HSCT), którą do niedawna zalecano tylko u chorych bez VGPR po pierwszym zabiegu i w praktyce rzadko wykonywano. Postępowanie takie jest jednak kwestionowane $\mathrm{w}$ dobie nowych leków. W retrospektywnej analizie pacjentów leczonych w terapii indukującej bortezomibem dowiedziono, że korzyść $z$ tandemowego auto-HSCT odnoszą chorzy obciążeni następującymi czynnikami ryzyka: brakiem całkowitej odpowiedzi po leczeniu indukującym, 
wyjściowym stadium zaawansowania ISS (International Staging System) 3 oraz niekorzystnymi aberracjami cytogenetycznymi, tj. $\mathrm{t}(4 ; 14)$ albo del(17p) [16]. W przypadku chorych obciążonych przynajmniej dwoma $z$ wyżej wymienionych czynników ryzyka zastosowanie podwójnej transplantacji wiązało się $z$ wydłużeniem PFS z 21 do 42 miesięcy $(\mathrm{p}=0,006)$, a OS - z 31,5 do 67 miesięcy ( $<<0,001)$ [16]. Wydaje się więc, że obecnie kwalifikacja do tandemowego auto-HSCT powinno być oparta na powyższych parametrach i częściej stosowana.

Natomiast w odniesieniu do allo-HSCT rozczarowaniem były wyniki dużego amerykańskiego badania randomizowanego (Blood and Marrow Transplant Clinical Trials Network 0102), w którym porównano tandemowy auto-HSCT $z$ kombinacją auto-HSCT i allo-HSCT ze zredukowanym kondycjonowaniem (RIC, reduced-intensity conditioning); wzięło w nim udział ponad 700 chorych z 43 amerykańskich ośrodków hematologicznych [21]. Zastosowanie RIC-allo-HSCT nie wiązało się $z$ przedłużeniem PFS ani OS zarówno w grupie standardowego, jak i wysokiego ryzyka nawrotu [21]. Obserwowano również wyższą umieralność wczesną w grupie poddanej auto-HSCT $z$ RIC-allo-HSCT, choć była znacznie niższa niż oczekiwana w przypadku transplantacji mieloablacyjnej. Obecnie należy przyjąć, że nie ma wskazań do rutynowego allo-HSCT w leczeniu chorych na PCM, poza protokołami badań klinicznych [21].

\section{Pacjenci niekwalifikujący się do auto-HSCT}

W zakresie leczenia tej grupy pacjentów najistotniejsze problemy, którym próbowano zaradzić w ostatnich latach, dotyczyły wyboru optymalnego schematu indukującego remisję oraz dostosowania intensywności i rodzaju leczenia do wieku, stanu sprawności i obecności chorób towarzyszących.

Najbardziej istotne dla terapii pacjentów starszych były analizy badań 3 . fazy porównujące dawny standard MP (melfalan, prednizon) z nowszymi propozycjami rozszerzenia tego schematu o nowe leki. Odległe wyniki randomizowanego badania VISTA, w którym porównywano schemat MP ze schematem MPV (melfalan, prednizon, bortezomib), wykazały po ponad 5-letnim okresie obserwacji utrzymującą się zdecydowaną przewagę schematu MPV, przy czym różnica OS wynosiła aż 13,3 miesiąca [22]. Skuteczność MPV wypada korzystnie w stosunku do standardowego schematu MPT (melfalan, prednizon, talidomid), ponieważ metaanaliza sześciu badań, w których porównywano schemat MPT ze schematem MP, wykazała różnicę w OS tylko na poziomie 6 miesięcy [23]. Mimo potencjalnie korzystnych wyników włoskiego badania randomizowanego, w którym porównywano schemat VMP $z$ podobnym schematem rozszerzonym $o$ talidomid i leczenie podtrzymujące talidomidem i bortezomibem (VMPT + VT), powszechnie uważa się, że jest to leczenie zbyt toksyczne u większości chorych niekwalifikujących się do auto-HSCT [24]. Schemat MPV podawany przez 9 cykli jest obecnie jedną $z$ dwóch preferowanych opcji leczenia w tej grupie chorych [22].

Drugą, bardzo interesującą, opcję wyłoniło ostatnio badanie FIRST prowadzone przez francuską grupę IFM (Intergroupe Français du Myélome). W badaniu tym 1623 chorych na PCM przydzielono losowo do leczenia zgodnie $z$ jednym $z$ trzech schematów: LDex stosowanym do progresji choroby, LDex podawanym przez 72 tygodnie (18 cykli) oraz standardowym MPT stosowanym przez 72 tygodnie (12 cykli) [25]. Wyniki badania wskazały na przewagę LDex kontynuowanego do progresji PCM, w tym uzyskano obniżenie ryzyka progresji choroby o około $30 \%$. Ponadto LDex stosowany do progresji był dobrze tolerowany i nie powodował zwiększonej częstości w tórnych nowotworów [25]. Badanie FIRST wyznaczyło nowy standard leczenia osób w tej grupie wiekowej, prawdopodobnie porównywalny pod względem aktywności z najlepszym dotychczas leczeniem według schematu VMP.

Drugim bardzo ważnym kierunkiem badań $\mathrm{w}$ tej grupie chorych są próby indywidualizacji leczenia względem stanu sprawności chorych. Szczególnie u pacjentów w podeszłym wieku i/lub $z$ obciążającymi chorobami towarzyszącymi zastosowanie zbyt intensywnego schematu może prowadzić do powikłań i konieczności przerwania leczenia lub znacznego zmniejszenia dawek leków. Dowiedziono również, że stan biologiczny pacjenta, zobiektyzowany dzięki ocenie geriatrycznej, jest niezależnym od zaawansowania i biologii PCM czynnikiem prognostycznym [26]. Na podstawie tych badań potrzeba włączenia obiektywnej oceny stanu sprawności do rutynowego postępowania u pacjentów starszych nie budzi obecnie wątpliwości [26]. Ostatnio, na podstawie analiz retrospektywnych badań klinicznych oraz opinii ekspertów, zaproponowano schemat zmniejszenia dawek zależnie od wieku chorych, stanu sprawności oraz chorób towarzyszących [27]. Należy również podkreślić, że w odniesieniu do możliwości redukcji toksyczności leczenia istotny postęp stanowią nowe metody stosowania bortezomibu. W retrospektywnej analizie kilku badań klinicznych u chorych powyżej 65. roku życia potwierdzono 
znaczne zmniejszenie częstości polineuropatii w przypadku stosowania bortezomibu raz w tygodniu, bez wpływu na skuteczność leczenia [28]. Istotny postęp stanowią również wyniki międzynarodowego badania randomizowanego MMY-3021, w którym porównywano podskórną i dożylną drogę podania bortezomibu u chorych na nawrotowego lub opornego PCM [29]. Podczas analizy wyników leczenia u 222 chorych $z 53$ ośrodków stwierdzono znacznie mniejszy odsetek polineuropatii przy identycznej skuteczności [29]. Z perspektywy czasu można już powiedzieć, że ten znacznie wygodniejszy i bezpieczniejszy sposób leczenia stał się postępowaniem standardowym.

\section{Terapie konsolidująca i podtrzymująca}

Leczenie konsolidujące po auto-HSCT, rozumiane jako podanie kilku cykli chemioterapii identycznej lub podobnej do stosowanej w leczeniu indukującym, staje się powoli postępowaniem standardowym w leczeniu chorych na PCM, choć dotychczas nie wykazano jego korzystnego wpływu na OS [30].

Natomiast nierozstrzygniętym tematem pozostaje terapia podtrzymująca po auto-HSCT. W badaniu 3. fazy prowadzonym przez grupy badawcze HOVON i GMMG-4, w którym porównano grupę poddaną leczeniu indukującemu remisję według schematu PAD i podtrzymywaniu po auto-HSCT bortezomibem $z$ grupą, w której w leczeniu indukującym stosowano VAD, a w leczeniu podtrzymującym po auto-HSCT talidomid [16], wykazano, że leczenie podtrzymujące $z$ bortezomibem było mniej toksyczne niz talidomid (odsetki wyłączenia $z$ powodu toksyczności 9\% v. 31\%) [16]. Mimo przewagi bortezomibu długoterminowe stosowanie tego leku jest również trudne ze względu na neurotoksyczność oraz konieczność podawania parenteralnego.

$Z$ tych względów spośród leków obecnie zarejestrowanych najbardziej obiecującym jest lenalidomid. W 2010 roku przedstawiono raporty $z$ dwóch dużych randomizowanych badań 3. fazy, w których porównywano leczenie podtrzymujące lenalidomidem po terapii dużymi dawkami melfalanu wspomaganej auto-HSCT [31, 32]. W badaniu francuskiej grupy IFM (badanie IFM 2005 02) 307 pacjentów włączono do grupy poddanej leczeniu podtrzymującemu lenalidomidem, a 307 chorych — do grupy otrzymującej placebo [31]. Badanie przerwano po pierwszej analizie wyników ze względu na ewidentną przewagę lenalidomidu (mediana PFS 42 v. 24 miesiące, $\mathrm{p}<10^{-8}$ ) [31]. W podobnie skonstruowanym badaniu amerykańskim (CALGB 100104), do którego zakwalifikowano łącznie 460 chorych, uzyskano 61-procentową redukcję ryzyka progresji lub zgonu u pacjentów otrzymujących lenalidomid [32]. W obu badaniach leczenie podtrzymujące lenalidomidem było bardzo dobrze tolerowane. Wyniki obu badań zgodnie wskazują na bardzo korzystny wplyw podtrzymywania lenalidomidem na PFS, ale są rozbieżne pod kątem wpływu na OS, ponieważ tylko w badaniu amerykańskim zaobserwowano jego wydłużenie $[31,32]$. Ponadto stwierdzono zwiększenie częstości wtórnych nowotworów, którego mechanizm pozostaje niewyjaśniony do dziśs [31, 32]. Późniejsza metaanaliza czterech przeprowadzonych dotychczas badań $z$ podtrzymywaniem lenalidomidem wskazuje na istotne wydłużenie PFS i trend w kierunku przedłużenia OS, ale również na wyższe ryzyko wtórnych nowotworów i innych powikłań, między innymi neutropenii [33]. $Z$ tych względów debata dotycząca celowości oraz sposobu stosowania leczenia podtrzymującego lenalidomidem po auto-HSCT obecnie pozostaje nierozstrzygnięta.

Interesującą perspektywą w przyszłości wydaje się zastosowanie w leczeniu podtrzymującym nowych doustnych IP pozbawionych istotnego ryzyka neurotoksycznosci. Bardzo interesujące obserwacje dotyczyły badania 2 . fazy służącego ocenie indukcji remisji za pomocą kombinacji nowego, doustnego inhibitora proteasomu - iksazomibu, lenalidomidu i deksametazonu $z$ następowym leczeniem podtrzymującym iksazomibem. U 48\% pacjentów uzyskano pogłębienie odpowiedzi podczas podtrzymywania iksazomibem. Co istotne, jedynie $10 \%$ chorych wymagało zmniejszenia dawki leku z powodu działań niepożądanych [18]. Te wstępne obserwacje wskazują, że iksazomib i prawdopodobnie inne doustne IP mogą być atrakcyjną opcją leczenia podtrzymującego u chorych na PCM w przyszłości.

\section{Leczenie chorych na nawrotowa/oporną postać PCM}

W ostatnich latach obserwuje się gwałtowny rozwój nowych terapii, przy czym leki o potwierdzonej skuteczności w leczeniu choroby nawrotowej i opornej z czasem zaczynają być stosowane w I linii. Do najbardziej obiecujących grup nowych leków o już udowodnionej skuteczności należą nowe IP (karfilzomib, iksazomib), IMiD III generacji (pomalidomid), inhibitory deacetylazy histonów (HDAC, histone deacetylase) (panobinostat i worinostat) oraz przeciwciała monoklonalne (szczególnie elotuzumab, daratumumab, SAR650984) [34]. 
Spośród bardzo szerokiej liczby jeszcze nowszych leków testowanych we wczesnych fazach badań klinicznych ostatnio największym zainteresowaniem cieszą się ARRY-520 - lek z całkowicie nowej grupy inhibitorów wrzeciona kariokinetycznego — oraz wybiórczy inhibitor HDAC 6 - ACY1215 [34].

W odniesieniu do aktualnej praktyki klinicznej szczególnie oczekiwane są leki, które wykażą skuteczność u pacjentów opornych na bortezomib i lenalidomid. W badaniu 2. fazy zaobserwowano, że 11/34 (32\%) pacjentów opornych na lenalidomid osiąga przynajmniej częściową odpowiedź na leczenie kombinacją pomalidomidu i deksametazonu [35]. Natomiast badacze z Multiple Myeloma Research Consortium stwierdzili przynajmniej częściową odpowiedź po leczeniu karfilzomibem u 6/34 (18\%) chorych opornych na bortezomib [36]. Natomiast jednym $z$ bardziej istotnych doniesień w ostatnich latach są wyniki badania APIRE [37], w którym porównano terapię według schematu KRD (karfilzomib, lenalidomid, deksametazon) oraz standardowe leczenie za pomocą schematu LDex w grupie 792 chorych $z$ nawrotem PCM po 1-3 liniach leczenia. Wykazano istotną przewage KRD pod kątem całkowitego odsetka odpowiedzi (ORR, overall response rate) (87v. 67\%) i PFS (26,3 $v \cdot 17,6$ miesiąca), a także trend do przedłużenia OS [37]. Korzyść z leczenia KRD zanotowano we wszystkich analizowanych podgrupach pacjentów. Co istotne, schemat ten charakteryzował się również bardzo dobrą tolerancją [37]. Na podstawie obiecujących wyników tego badania schemat KRD może się stać nowym standardem w leczeniu chorych na nawrotową/oporną postać PCM.

Obok nowych IP oraz IMiD, do najbardziej obiecujących leków u chorych na PCM należą przeciwciała monoklonalne [34, 38]. Cząsteczki te są obecnie testowane głównie w PCM nawrotowym/opornym, ale w przyszłości $z$ dużym prawdopodobieństwem staną się również uzupełnieniem terapii pierwszego rzutu. Bardzo zaawansowane są badania elotuzumabu - humanizowanego przeciwciała klasy IgG skierowanego przeciwko powszechnie występującej na komórkach PCM glikoproteinie SLAMF7. W badaniu 2. fazy testowano dwa sposoby dawkowania elotuzumabu - 10 i $20 \mathrm{mg} / \mathrm{kg} \mathrm{mc}$, $\mathrm{w}$ skojarzeniu $\mathrm{z}$ lenalidomidem i deksametazonem [39]. Choć elotuzumab wykazuje minimalne działanie przeciwszpiczakowe w monoterapii, to wydaje się zwiększać aktywność LDex, przy czym w bardziej obiecującej kombinacji (elotuzumab w dawce $10 \mathrm{mg} / \mathrm{m}^{2}$ ) stwierdzono satysfakcjonujący ORR na poziomie $92 \%$ i PFS wynoszące 32,5 miesiąca [39].
Jeżeli te wyniki uda się potwierdzić w trwających od pewnego czasu badaniach klinicznych 3. fazy (ELOQUENT-1 i ELOQUENT-2), to elotuzumab ma szansę stać się podstawą immunochemioterapii u chorych na PCM [40].

Obecnie w tej grupie leków największe nadzieje budzą przeciwciała anty-CD38, wśród których najbardziej zaawansowane w rozwoju klinicznym są daratumumab i SAR650984 [38, 41]. Leki te testowano $z$ wielką ostrożnością, ponieważ antygen CD38 występuje na wielu typach komórek i jest odpowiedzialny za ważne funkcje, w tym kontrolę sekrecji niektórych hormonów, jednak tolerancja okazała się dobra [38].W badaniu fazy $1 / 2$, służącym ocenie skojarzenia daratumumabu $z$ lenalidomidem i deksametazonem, uzyskano 75\% odpowiedzi klinicznych wśród dotychczas ocenionych 20 chorych $z$ nawrotowym/opornym PCM [42]. Przedstawiono również interesujące badanie fazy $1 \mathrm{~b}$, w którym daratumumab kojarzono ze standardowymi schematami terapii stosowanymi obecnie w różnych fazach leczenia, między innymi $z$ VD, VTD i pomalidomidem $z$ deksametazonem [43]. Wstępne wyniki badania sugerują, że dołączenie daratumumabu zwiększa skuteczność tych schematów bez dodatkowych, nieprzewidzianych działań niepożądanych.

\section{Leczenie wspomagające}

W ostatnich latach dokonano niewielu odkryć dotyczących leczenia wspomagającego. Jednak na uwagę zasługują z pewnością wyniki randomizowanego porównania dwóch bisfosfonianów — kwasu zolendronowego stosowanego dożylnie i klodronianu disodowego stosowanego doustnie, które przeprowadzano w ramach dużego angielskiego badania MRC IX [44]. Porównywano w nim różne schematy intensywnej i nieintensywnej chemioterapii I linii u blisko 2 tys. chorych na PCM. Stwierdzono przewagę kwasu zolendronowego pod względem redukcji liczby incydentów kostnych, ale również pod względem odsetka odpowiedzi, PFS i OS [44]. Zaskoczeniem był fakt, że pozytywny efekt działania kwasu zolendronowego był widoczny także u pacjentów, u których nie stwierdzono choroby kostnej. Autorzy wiążą korzystny wpływ kwasu zolendronowego na przeżycie $z$ wcześniej stwierdzonym efektem przeciwnowotworowym tego leku. Wyniki tego badania istotnie wpłynęły na standard postępowania w PCM. Obecnie w profilaktyce powikłań kostnych zdecydowanie preferuje się kwas zolendronowy, a leczenie stosuje się u wszystkich pacjentów ze wskazaniami 
do chemioterapii, niezależnie od występowania zmian osteolitycznych.

\section{Podsumowanie}

Od prawie dwóch dekad dokonuje się niezwykły postęp w leczeniu chorych na PCM wyrażany ciągłą poprawą rokowania. Należy jednak zauważyć, że ta ogólna poprawa jest przede wszystkim efektem coraz lepszych wyników uzyskiwanych u chorych $z$ grupy standardowego ryzyka. Natomiast postęp w leczeniu chorych $z$ grupy wysokiego ryzyka jest niewielki i w tym zakresie nowe strategie terapeutyczne są najbardziej oczekiwane. $\mathrm{Na}$ podstawie omówionych w pracy postępów można wyróżnić dwa dominujące kierunki; po pierwsze, dzięki długookresowym obserwacjom populacji leczonych w ramach dużych, randomizowanych badań klinicznych 3. fazy, następuje stała optymalizacja obowiązującej obecnie strategii leczenia. Polega ona na wyborze najskuteczniejszych i najlepiej tolerowanych schematów chemioterapii opartych przede wszystkim na lekach $z$ grup IP i IMiD oraz ich włączeniem $\mathrm{w}$ odpowiednie fazy leczenia indukującego, konsolidującego i podtrzymującego remisję. Zauważalne są również tendencje do zastępowania starszych generacji IP i IMiD przez nowsze leki charakteryzujące się większą aktywnością i lepszą tolerancją, a ponadto wyraźniejsza staje się potrzeba kontynuowania leczenia podtrzymującego do progresji choroby. Po drugie trwają intensywne poszukiwania nowych markerów rokowniczych, nowych celów terapeutycznych i nowych terapii, które w przyszłości pozwoliłyby $z$ jednej strony na indywidualizację leczenia, a $z$ drugiej na przełamywanie oporności na wcześniej stosowane leki. Spośród nowych leków największe nadzieje budzą obecnie przeciwciała monoklonalne, w tym szczególnie przeciwciała skierowane przeciwko antygenowi CD38. Dalszy rozwój immunoterapii może w bliskiej przyszłości w istotny sposób wpłynąć na obecny model leczenia chorych na PCM.

\section{Piśmiennictwo}

1. Singhal S., Mehta J., Desikan R. i wsp. Antitumor activity of thalidomide in refractory multiple myeloma. N. Engl. J. Med. 1999; 341: 1565-1571.

2. Kumar S. Treatment of newly diagnosed multiple myeloma: advances in current therapy. Med. Oncol. 2010; 27 (supl. 1): S14-S24.

3. Kumar S., Dispenzieri A., Lacy M.Q. i wsp. Continued improvement in survival in multiple myeloma: changes in early mortality and outcomes in older patients. Leukemia 2014; 28: 1122-1128.
4. Ito T., Ando H., Suzuki T. i wsp. Identification of a primary target of thalidomide teratogenicity. Science 2010; 327: 1345-1350.

5. Krönke J., Udeshi N.D., Narla A. i wsp. Lenalidomide causes selective degradation of IKZF1 and IKZF3 in multiple myeloma cells. Science 2014; 343: 301-305.

6. Lu G., Middleton R.E., Sun H. i wsp. The myeloma drug lenalidomide promotes the cereblon-dependent destruction of Ikaros proteins. Science 2014; 343: 305-309.

7. Keats J.J., Chesi M., Egan J.B. i wsp. Clonal competition with alternating dominance in multiple myeloma. Blood 2012; 120: 1067-1076.

8. Egan J.B., Shi C.X., Tembe W. i wsp. Whole-genome sequencing of multiple myeloma from diagnosis to plasma cell leukemia reveals genomic initiating events, evolution, and clonal tides. Blood 2012; 120: 1060-1066.

9. Magrangeas F., Avet-Loiseau H., Gouraud W. i wsp. Minor clone provides a reservoir for relapse in multiple myeloma. Leukemia 2013; 27: 473-481.

10. Bladé J., de Larrea C.F., Rosiñol L. Extramedullary involvement in multiple myeloma. Haematologica 2012; 97: 1618-1619.

11. Usmani S.Z., Heuck C., Mitchell A. i wsp. Extramedullary disease portends poor prognosis in multiple myeloma and is overrepresented in high-risk disease even in the era of novel agents. Haematologica 2012; 97: 1761-1767.

12. Zamagni E., Patriarca F., Nanni C. i wsp. Prognostic relevance of 18-F FDG PET/CT in newly diagnosed multiple myeloma patients treated with up-front autologous transplantation. Blood 2011; 118: 5989-5995.

13. Mai E.K., Hielscher T., Kloth J.K. i wsp. A magnetic resonance imaging-based prognostic scoring system to predict outcome in transplant-eligible patients with multiple myeloma. Haematologica. 2015 Mar 20. pii: haematol.2015.124115 [złożone do druku].

14. Mateos M.V., Hernández M.T., Giraldo P. i wsp. Lenalidomide plus dexamethasone for high-risk smoldering multiple myeloma. N. Engl. J. Med. 2013; 369: 438-447.

15. Rajkumar S.V., Dimopoulos M.A., Palumbo A. i wsp. International Myeloma Working Group updated criteria for the diagnosis of multiple myeloma. Lancet Oncol. 2014; 15: e538-e548.

16. Sonneveld P., Schmidt-Wolf I.G., van der Holt B. i wsp. Bortezomib induction andmaintenance treatment in patients with newly diagnosed multiple myeloma: results of the randomized phase III HOVON-65/ GMMG-HD4 trial. J. Clin. Oncol. 2012; 30: 2946-2955.

17. Cavo M., Pantani L., Pezzi A. i wsp. Superior efficacy of VTD over VCD as induction therapy for autotransplantation-eligible, newly diagnosed, myeloma patients. Blood 2014; 124: abstrakt 197.

18. Kumar S.K., Berdeja J.G., Niesvizky R. i wsp. Safety and tolerability of ixazomib, an oral proteasome inhibitor, in combination with lenalidomide and dexamethasone in patients with previously untreated multiple myeloma: an open-label phase 1/2 study. Lancet Oncol. 2014; 15: 1503-1512.

19. Kumar S.K., Lacy M.Q., Dispenzieri A. i wsp. Early versus delayed autologous transplantation after immunomodulatory agents-based induction therapy in patients with newly diagnosed multiple myeloma. Cancer 2012; 118: 1585-1592.

20. Moreau P., Attal M. All transplantation eligible patients with myeloma should receive ASCT in first response. Hematology Am. Soc. Hematol. Educ. Program 2014; 2014: 250-254.

21. Krishnan A., Pasquini M.C., Logan B. i wsp. Autologous haemopoietic stem-cell transplantation followed by allogeneic or 
autologous haemopoietic stem-cell transplantation in patients with multiple myeloma (BMT CTN 0102): a phase 3 biological assignment trial. Lancet Oncol. 2011; 12: 1195-1203.

22. San Miguel J.F., Schlag R., Khuageva N.K. Persistent overall survival benefit and no increased risk of second malignancies with bortezomib-melphalan-prednisone versus melphalan-prednisone in patients with previously untreated multiple myeloma. J. Clin. Oncol. 2013; 31: 448-455.

23. Fayers P.M., Palumbo A., Hulin C. i wsp. Thalidomide for previously untreated elderly patients with multiple myeloma: metaanalysis of 1685 individual patient data from 6 randomized clinical trials. Blood 2011; 118: 1239-1247.

24. Palumbo A., Bringhen S., Larocca A. Bortezomib-melphalan-prednisone-thalidomide followed by maintenance with bortezomib-thalidomide compared with bortezomib-melphalan-prednisone for initial treatment of multiple myeloma: updated follow-up and improved survival. J. Clin. Oncol. 2014; 32: 634-640.

25. Benboubker L., Dimopoulos M.A., Dispenzieri A. i wsp. Lenalidomide and dexamethasone in transplant-ineligible patients with myeloma. N. Engl. J. Med. 2014; 371: 906-917.

26. Bringhen S., Mateos M.V., Zweegman S. i wsp. Age and organ damage correlate with poor survival in myeloma patients: metaanalysis of 1435 individual patient data from 4 randomized trials. Haematologica 2013; 98: 980-987.

27. Palumbo A., Mina R. Management of older adults with multiple myeloma. Blood Rev. 2013; 27: 133-142.

28. Bringhen S., Larocca A., Rossi D. i wsp. Efficacy and safety of once-weekly bortezomib in multiple myeloma patients. Blood 2010; 116: 4745-4753.

29. Arnulf B., Pylypenko H., Grosicki S. i wsp. Updated survival analysis of a randomized phase III study of subcutaneous versus intravenous bortezomib in patients with relapsed multiple myeloma. Haematologica 2012; 97: 1925-1928.

30. Mellqvist U.H., Gimsing P., Hjertner O. i wsp. Bortezomib consolidation after autologous stem cell transplantation in multiple myeloma: a Nordic Myeloma Study Group randomized phase 3 trial. Blood 2013; 121: 4647-4654.

31. Attal M., Lauwers-Cances V., Marit G. i wsp. Lenalidomide maintenance after stem-cell transplantation for multiple myeloma. N. Engl. J. Med. 2012; 366: 1782-1791.

32. McCarthy P.L., Owzar K., Hofmeister C.C. Lenalidomide after stem-cell transplantation for multiple myeloma. N. Engl. J. Med. 2012; 366: 1770-1781.
33. Yang B., Yu R.L., Chi X.H., Lu X.C. Lenalidomide treatment for multiple myeloma: systematic review and meta-analysis of randomized controlled trials. Plos One 2013; 8: e64354.

34. Ocio E.M., Mitsiades C.S., Orlowski R.Z., Anderson K.C. Future agents and treatment directions in multiple myeloma. Expert Rev. Hematol. 2014; 7: 127-141.

35. Lacy M.Q., Allred J.B., Gertz M.A. i wsp. Pomalidomide plus low-dose dexamethasone in myeloma refractory to both bortezomib and lenalidomide: comparison of 2 dosing strategies in dual-refractory disease. Blood 2011; 118: 2970-2975.

36. Siegel D.S., Martin T., Wang M. i wsp. A phase 2 study of singleagent carfilzomib (PX-171-003-A1) in patients with relapsed and refractory multiple myeloma. Blood 2012; 120: 2817-2825.

37. Stewart A.K., Rajkumar S.V., Dimopoulos M.A. i wsp. Carfilzomib, lenalidomide, and dexamethasone for relapsed multiple myeloma. N. Engl. J. Med. 2015; 372: 142-152.

38. Laubach J.P., Richardson P.G. CD38-Targeted Immunochemotherapy in refractory multiple myeloma: a new horizon. Clin Cancer Res. 2015 Apr 15. pii:clincanres.3190.2015 [złożone do druku].

39. Lonial S., Vij R., Harousseau J.L. i wsp. Lotuzumab in combination with lenalidomide and low-dose dexamethasone in relapsed or refractory multiple myeloma. J. Clin. Oncol. 2012; 30: 1953-1959.

40. van de Donk N.W., Kamps S., Mutis T., Lokhorst H.M. Monoclonal antibody-based therapy as a new treatment strategy in multiple myeloma. Leukemia 2012; 26: 199-213.

41. van der Veer M.S., de Weers M., van Kessel B. i wsp. Towards effective immunotherapy of myeloma: enhanced elimination of myeloma cells by combination of lenalidomide with the human CD38 monoclonal antibody daratumumab. Haematologica 2011; 96: 284-290.

42. Plesner T., Arkenau H.-T., Lokhorst H.M. i wsp. Safety and efficacy of daratumumab with lenalidomide and dexamethasone in relapsed or relapsed, refractory multiple myeloma. Blood 2014; 124: abstrakt 84.

43. Moreau P., Mateos M.V., Bladé J. i wsp. An open-label, multicenter, phase $1 b$ study of daratumumab in combination with backbone regimens in patients with multiple myeloma. Blood 2014; 124: abstrakt 84.

44. Morgan G.J., Davies F.E., Gregory W.M. i wsp. First-line treatment with zoledronic acid as compared with clodronic acid in multiple myeloma (MRC Myeloma IX): a randomized controlled trial. Lancet 2010; 376: 1989-1999. 